\title{
Preparation of Gel Alcohol Flavored with Essential Oils. An Employ of Laboratory Techniques in the Organic Chemistry Study
}

\author{
Vanina A. Guntero ${ }^{1,2,3}$, María N. Kneeteman ${ }^{1,2}$, Pedro M. Mancini ${ }^{1,2, *}$ \\ ${ }^{1}$ Departamento de Química, Facultad de Ingeniería Química (FIQ), Universidad Nacional del Litoral (UNL), Santa Fe, 3000, Argentina \\ ${ }^{2}$ Instituto de Química del Litoral (IQAL), Universidad Nacional del Litoral - Consejo Nacional de Investigaciones Científicas y \\ Técnicas (CONICET), Santa Fe, 3000, Argentina \\ ${ }^{3}$ Universidad Tecnológica Nacional (UTN), Facultad Regional San Francisco, San Francisco, 2400, Argentina \\ *Corresponding author: pmancini@fiq.unl.edu.ar
}

\begin{abstract}
The main aim of this work is to teach chemistry through a practical application. In it is described a chemical experiment for high school students. They learn fundamental concepts through the preparation of gel alcohol flavored. The experiment has four stages: search information, cultivation of aromatic plants, extraction of essential oils, and elaboration of gel alcohol. The hydro distillation technique was applied in order to obtain the corresponding essential oil. The aromatic plants used were cloves, lavender, rosemary, salvia and cedron. The essential oils were analyzed by gas chromatography. The experiment demonstrated to the students the application of chemistry for the preparation of personal care products making concepts more tangible than a simple reading.
\end{abstract}

Keywords: natural products, essential oils, organic chemistry, high school chemistry, aromatic plants, gel alcohol

Cite This Article: Vanina A. Guntero, María N. Kneeteman, and Pedro M. Mancini, "Preparation of Gel Alcohol Flavored with Essential Oils. An Employ of Laboratory Techniques in the Organic Chemistry Study." World Journal of Chemical Education, vol. 5, no. 3 (2017): 86-90. doi: 10.12691/wjce-5-3-1.

\section{Introduction}

Science education research verifies that heightened student interest and engagement occur when laboratory activities parallel "real" research methods [1]. As well modern learning environments must be properly designed to facilitate active and collaborative learning processes, to help students understand and not only to memorize $[2,3]$. Meaningful learning is possible in the laboratory if students have the opportunities to manipulate equipment and materials in order to be able to construct their knowledge of phenomena and related scientific concepts [4]. According to that, we propose the study of organic chemistry through laboratory techniques and natural products (see in Table 1 the goals to teach chemistry). The high school, in which this work was realized, has relation with agricultural production. The students in this school obtain comprehension in the following topics: cultivation of aromatic species (rosemary, salvia, lavender, cedron and cloves), extraction of essential oils (EOs), and in their use in the elaboration of gel alcohol. This project will allow students to apply previously studied contents such as functional groups, and molecular structure. Moreover they learn on essential oils and their properties, extraction and separation techniques, solubility, density, and viscosity.

Some natural products are used in personal care products preparations. Topics related to cosmetics are popular in the students [5]. EOs when are incorporated into different products produce many benefaction. For example, $d$-limonene, geranyl acetate or $d$-carvone are employed in perfumes, creams, soaps, as flavour additives for food, in fragrances for household cleaning products and as industrial solvents. Moreover, EOs are used most frequently in aromatherapy [6].

Products of personal and domestic hygiene play an important role in disease prevention. Particularly the alcohol gel is a disinfectant used to kill bacteria and viruses from our hands, and their use is one of the preventive measures against the spread of infectious diseases such as influenza. Then the preparation of gel alcohol flavored by EOs offer a good combination.

The principal aim of this work is related with teach chemistry through a practical application using normal laboratory techniques.

Table 1. Goals to teach chemistry

\begin{tabular}{|c|}
\hline Stimulate the interest of students \\
\hline Inspire them to seek the scientific spirit \\
\hline Help students to develop positive attitudes about the science courses \\
\hline
\end{tabular}

\subsection{Stages of this Educational Activity}

This experiment was divided in four stages (Figure 1).

In the first, the class (15 students) was divided into teams of 3 students each. They looked for information of reagent data sheets, extraction methods of EOs, functional 
groups, physical and chemical properties, and molecular structures of the ingredients corresponding to gel alcohol.

In the second stage, the students learn about management and collection of aromatic plants.

The third stage involves the extraction of EOs through hydro distillation [7]. This is the method of reference. They are widely used because they are easy to install, cheap, safe, light to operate and it has low energy consumption.

The fourth stage consisted in the preparation of gel alcohol. The chemical ingredients used were EOs, carbopol, triethanolamine, glycerin, ethyl alcohol, and distilled water. They have different functions: water is the diluent; carbopol is the thickener; alcohol is the sanitizer; glycerin is a water-soluble compound and humectant, moreover it allows manipulated the viscosity of the gel; triethanolamine is the neutralizing which render possible that the gel can tolerate high alcohol concentrations, and the EOs give the aroma to the preparation.

\subsection{Essential Oils}

Aromatic plants and their essential oils have been used since antiquity in flavor and fragrances, as condiment or spice, in medicines, as antimicrobial/insecticidal agents, and to repel insect or protect stored products [8]. EO is a fragrance and volatile oily liquids obtained from plant material. They are normally formed in special cells or groups of cells, found in leaves and stems, and commonly concentrated in one particular region such as leaves, bark or fruit [9]. The constituents of an essential oil may be classified into two principal groups: hydrocarbons (terpenes, sesquiterpenes and diterpenes); oxygenated compounds derived from these hydrocarbons including alcohols, aldehydes, esters, ketones, phenols, carboxylic acids, etc. [10,11].

In this experience were used the following EOs:

Clove essential oil, isolated from the buds of Syzygium aromaticum, belonging to the Myrtaceae family, has been widely used in the flavoring industries, and for fragrance and cosmetics [12]. Clove oil has biological activities, such as antibacterial, antifungal, insecticidal and antioxidant properties [13]. The major component is eugenol followed by eugenyl acetate and $\beta$-caryophyllene [14].

The essential oils obtained from Lavandula species, contain a mixture of monoterpenes and are mainly utilized in personal care and hygiene products including soaps, shampoos, mouth washes, and industrial and household cleaners, among others [15]. The oil is also widely used in aromatherapy, and is known that this EO to have calming, antiflatulence, and anticolic properties [16]. The lavender essential oil have several components, with the prevalence of linalool, 1,8-cineole, linalyl acetate, camphor and borneol [17].

Rosemary (Rosmarinus officinalis L.) belongs to Lamiaceae family. It is a source of bioactive ingredients including phenolic acids, flavonoids, diterpenoids and triterpenes. This extracts are widely used as additives in food (e.g. flavorings, antioxidant and antimicrobial agent) and pharmaceutical (e.g. hepatoprotective, diuretic, hypocholesterolemic, antirheumatic and antithrombotic) industries $[18,19,20]$. The principal components of this EO from rosemary are 1,8-cineole, camphor, $\alpha$-pinene, and borneol [21].

Salvia is an important genus containing a great number of species of the Labiatae family; most species of Salvia are traditional herbal medicines and industrial materials with various active components. Besides is also evidently rich in essential oils and phenolic acids [22]. Salvia essential oil is also effective against several bacteria [23]. The first dominant constituents are cis-thujone, 1,8-cineole, camphor, trans-thujone, $\alpha$-humulene and linalool [24].

Cedron essential oil was isolated from the leaves of Aloysia triphylla belong to the Verbenaceae family [25]. Due to the component diversity of EOs, these plant products present diverse and relevant biological activities (e.g. antimicrobial, antiparasitic, antioxidant, immunomodulatory and anesthetic/sedative) [26]. The three main essential oil compounds present either in flowers or in leaves are geranial, neral, and limonene[27].

\section{Materials and Methods}

\subsection{Obtention of EOs}

\subsubsection{Plant material}

Fresh leaves of Rosemary, Lavandula, Cedron, Salvia and Cloves were collected from same location within in the East Province of Córdoba, Argentina. Plant matrix was dried to room temperature until constant weight and stored in plastic bags.

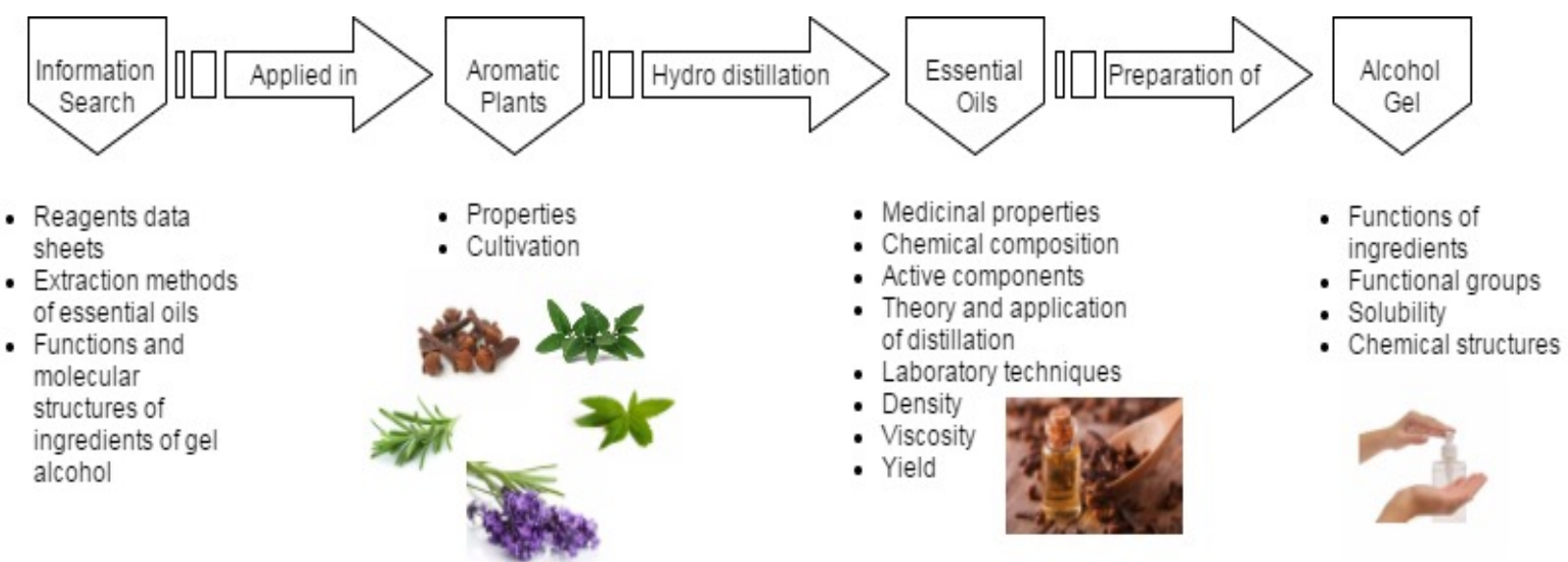

Figure 1. Stages of educational activity 


\subsubsection{Materials and Equipment}

The material and equipment that was used were: distilled water, round-bottom flask of $500 \mathrm{~mL}$, thermometer, condenser, heating mantles, and a separation funnel.

\subsubsection{Hydro distillation}

Dry plant matrix was milled with a mixer. Then it was put 10 grams in the round-bottom flask and added $350 \mathrm{ml}$ of water. The leaves were distilled by Clevenger type apparatus (Figure 2) for $3 \mathrm{~h}$. The distillate was extracted with $3 \times 10 \mathrm{ml}$ dichloromethane through liquid-liquid extraction. Subsequently, anhydrous sodium sulfate was added to remove some excess water in the organic layer and the solvent was evaporated.

Hydro distillations were performed three times for each sample and the mean values of the extraction yields were reported with its corresponding standard deviation.

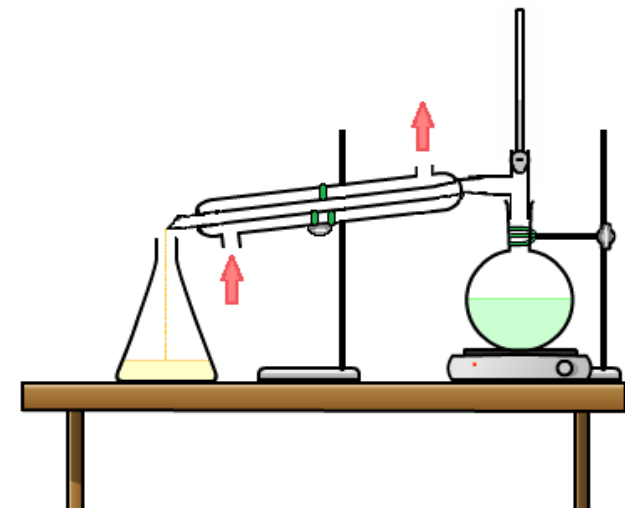

Figure 2. Clevenger type apparatus

\subsection{Preparation of alcohol gel}

\subsubsection{Materials and Equipment}

The materials and equipment used were: distilled water, carbopol, glycerin, triethanolamine, alcohol $96 \%$, beaker of $600 \mathrm{~mL}$, test tube $250 \mathrm{~mL}$, pasteur pipette, and glass rod.

\subsubsection{Procedure}

To $1 \mathrm{~g}$ of carbopol was added slowly and with continuous stirring distilled water through a glass rod until a transparent and viscous solution is obtained. Subsequently were added $250 \mathrm{~mL}$ of ethyl alcohol $96 \%, 8$ $\mathrm{mL}$ of glycerin, 6 drops of triethanolamine, and the corresponding EO (20 drops) observing an increase in the viscosity of the mixture. In the Table 2 it is shows the ingredients and their respective quantity.

Table 2. Ingredients used for the alcohol gel preparation

\begin{tabular}{|c|c|}
\hline Ingredients* & Quantity \\
\hline Carbopol & $1 \mathrm{~g}$ \\
Glycerin & $8 \mathrm{~mL}$ \\
Triethanolamine & 6 drops \\
Ethyl alcohol $96 \%$ & $250 \mathrm{~mL}$ \\
Distilled water & $140 \mathrm{~mL}$ \\
Essential oil & 20 drops \\
\hline
\end{tabular}

*The ingredients are used to prepare approximately $500 \mathrm{~mL}$ of alcohol gel.

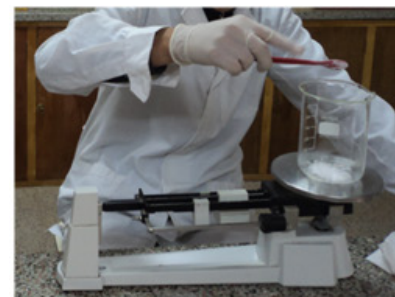

(a)

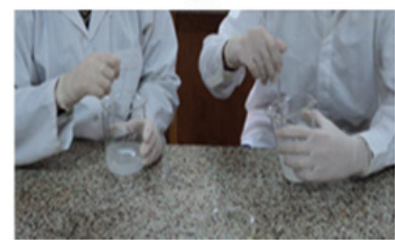

(c)

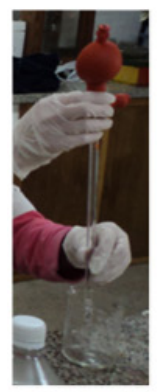

(e)

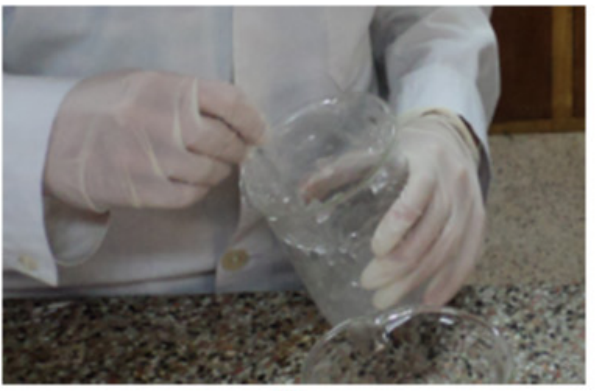

(f)

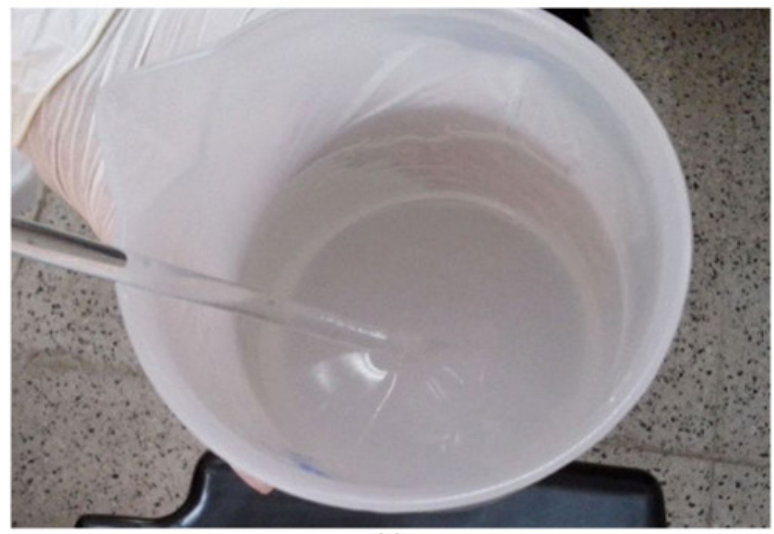

(g)

Figure 3. (a) Measurement of carbopol, (b) Added of distilled water, (c) Stirring, (d) Added of ethyl alcohol $96 \%$, (e) Added glycerin, triethanolamine and essential oil, (f) Stirring, (f) Gel alcohol

\section{Results and Discussion}

\subsection{Yield of Hydro Distillation}

Table 3 shows the average yields obtain for each EOs with their respective standard deviation. The yield was calculated by equation 1 .

$$
\text { Yield }(\%)=\frac{\text { mass of purified EOs }(g)}{\text { mass of dry plant matrix }(g)} * 100 \%
$$

Table 3. Results of hydro distillation

\begin{tabular}{|l|c|}
\hline Aromatic Plant & Yield (g Extract/g Essential oil) \\
\hline Cloves & $1.320 \pm 0.434$ \\
\hline Cedron & $1.850 \pm 0.314$ \\
\hline Rosemary & $2.006 \pm 0.452$ \\
\hline Lavender & $0.804 \pm 0.293$ \\
\hline Salvia & $2.685 \pm 0.325$ \\
\hline
\end{tabular}




\subsection{Identification of Essential Oils}

The composition of essential oil obtained coincides with that reported in the literature.

Gas chromatography (GC) analyses were performed using a Perkin Elmer Autosystem XL equipped with a FID and a megabore (di: $0.53 \mathrm{~mm})$ PE-5 \% (5 \% Phenylmethylpolysiloxane), length: $30 \mathrm{~m}$, film: $0.5 \mu \mathrm{m}$, temp. Limit: $300^{\circ} \mathrm{C}$.

The conditions by $\mathrm{EO}$ of clove were: oven temperature was $80^{\circ} \mathrm{C}$ for $2 \mathrm{~min}$, then programmed heating from 80 to $230^{\circ} \mathrm{C}$ at a rate of $6^{\circ} \mathrm{C} / \mathrm{min}$, and at $230^{\circ} \mathrm{C}$ for $2 \mathrm{~min}$. Injector and detector temperatures were $230^{\circ} \mathrm{C}$. The carrier gas, nitrogen, was adjusted to a linear velocity of $24 \mathrm{ml} / \mathrm{min}$. The samples were injected into the GC by split mode with a split ratio of $1 / 20$. Methyl salicylate was used as internal standard [13]. Figure 4 show the corresponding chromatogram. Taking into account the relative abundance of components, eugenol was found to be the major component $(30 \%)$. Other compounds identified in the clove extract were the following: caryophyllene $(6.2 \%)$ and eugenol acetate $(7.4 \%)$.

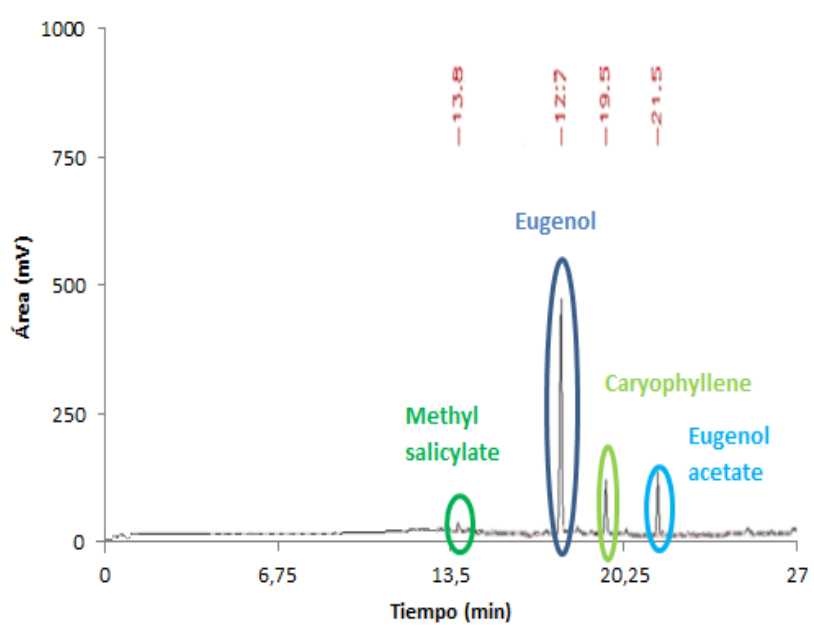

Figure 4. Gas chromatograms of the cloves essential oil

The conditions by EO of lavender were: initial column temperature was $60^{\circ} \mathrm{C}$ and programmed to increase at $4^{\circ} \mathrm{C} / \mathrm{min}$ to $280^{\circ} \mathrm{C}$. The split ratio was $40: 1$. The injector temperature was set at $300^{\circ} \mathrm{C}$. The oil content linalool (30\%), 1,8-cineole (20\%), linalyl acetate (18\%), camphor (4\%) and borneol (10\%).

The chromatographic conditions by EO of rosemary were: oven temperature was set at $40^{\circ} \mathrm{C}$ for $3 \mathrm{~min}$, then programmed from 40 to $100^{\circ} \mathrm{C}$ at a rate 1 of $10^{\circ} \mathrm{C} / \mathrm{min}$ until to reach $100^{\circ} \mathrm{C}$, from $100^{\circ} \mathrm{C}$ to $245^{\circ} \mathrm{C}$ at a rate of 2 of $15^{\circ} \mathrm{C} / \mathrm{min}$. The injector temperature was $250^{\circ} \mathrm{C}$ [28]. This essential oil content 1,8 cineole $(21 \%)$, camphor $(12 \%)$ and pinene $(10 \%)$.

The conditions by EO of salvia were: oven temperature was set at $70^{\circ} \mathrm{C}$ for $10 \mathrm{~min}$ and then reprogrammed from $70^{\circ} \mathrm{C}$ to $210^{\circ} \mathrm{C}$ at a rate of $3^{\circ} \mathrm{C} / \mathrm{min}$ [24]. This essential oil content thujone (43\%), 1,8-cineole (50\%) and linalool $(27 \%)$.

The conditions by EO of cedron were: oven temperature $40^{\circ} \mathrm{C}$ for $4 \mathrm{~min}$, then heating from 40 to $260^{\circ} \mathrm{C}$ at a rate of $4^{\circ} \mathrm{C} / \mathrm{min}$, and at $260^{\circ} \mathrm{C}$ for $2 \mathrm{~min}$. Injector and detector temperatures were $220^{\circ} \mathrm{C}$. Internal standard was a series of n-alkanes [29]. This essential oil contains geranial (35\%), neral (15\%) and limonene (12\%).

\subsection{Preparation of Different Gels}

Five gel alcohols were prepared with different fragrances: cloves, cedron, rosemary, lavender, salvia.

\section{Conclusion}

It has been possible to show that this work constitutes a good experience of laboratory for students of high school level. Through this experience the students can develop skills and abilities in the handling of equipment and techniques of laboratory. Besides, they understand the basic technology for the distillation process, and how to do cosmetic products. The students know in a directly way the principal components and use of essential oils. The oil extract incorporated to alcohol gel gives it a strong aroma improving their organoleptic properties. The preparation of gel alcohol flavored could be used in a commercial business. In parallel, has been possible to identify a number of essential oil from plant species from the area corresponding to the city of San Francisco province of Córdoba (Argentina).

Finally the students can learn how to work in teams, observe research methodology and analyze information.

\section{References}

[1] Daconta, L. V., Minger, T., Nedelkova V., and Zikopoulos, J. N., "Organic Chemistry and the Native Plants of the Sonoran Desert: Conversion of Jojoba Oil to Biodiesel," J. Chem. Educ., vol. 92, pp. 1741-1744, 2015.

[2] Kalathaki, M., "A Design Tool of Didactic Scenarios for Science Teaching in Secondary Education," Int. J. Adv. Res. Educ. Technol., vol. 3, no. 3, 2016.

[3] Borgobello, A., Peralta, N. S., and Roselli, N. D., "Interaction among experience, teaching performance and student's learning at university level," Estudos de Psicologia, vol. 30, pp. 169-176, 2013.

[4] Hofstein A., and Mamlok-Naaman, R., "The laboratory in science education : the state of the art," Chem. Educ. Res. Pract., vol. 8, no. 2, pp. 105-107, 2007.

[5] Liao, W., and Lien, C. Y., "Facial toner preparation using distilled Fragrant Compounds of natural herbal plants," J. Chem., vol. 88, no. 4, 2011.

[6] Bakkali, F., Averbeck, S., Averbeck, D., and Idaomar, M. "Biological effects of essential oils - A review," Food Chem. Toxicol., vol. 46, pp. 446-475, 2008.

[7] Linde, G. A., Colauto, N. B., Albertó, E., and Gazim, Z. C., "Quimiotipos, Extracción, Composición y Aplicaciones del Aceite Esencial de Lippia alba," Rev. Bras. Pl., vol. 18, pp. 191-200, 2016.

[8] Batish, D. R., Pal Singh, H., Kohli, R. K.., and Kaur, S., "Forest Ecology and Management Eucalyptus essential oil as a natural pesticide," For. Ecol. Manage., vol. 256, pp. 2166-2174, 2008.

[9] Gutierrez, J., Barry-Ryan, C., and Bourke, P., "International Journal of Food Microbiology The antimicrobial ef fi cacy of plant essential oil combinations and interactions with food ingredients," Int. J. Food Microbiol., vol. 124, pp. 91-97, 2008.

[10] Da Porto, C., Decorti, D., and Kikic, I., "Flavour compounds of Lavandula angustifolia L . to use in food manufacturing: Comparison of three different extraction methods," Food Chem., vol. 112, pp. 1072-1078, 2009.

[11] Calo, J. R., Crandall, P. G., O'Bryan, C. A., and Ricke, S. C., "Essential Oils as Antimicrobials in Food Systems- A Review," Food Control, vol. 54, pp. 111-119, 2015. 
[12] Sebaaly, C., Jraij, A., Fessi, H., Charcosset, C., and Greige-Gerges, H., "Preparation and characterization of clove essential oil-loaded liposomes," Food Chem., vol. 178, pp. 52-62, 2015.

[13] Wenqiang, G., Shufen, L., Ruixiang, Y., Shaokun, T., and Can, Q., "Food Chemistry Comparison of essential oils of clove buds extracted with supercritical carbon dioxide and other three traditional extraction methods," Food Chem., vol. 101, pp. 15581564, 2007.

[14] Alma, M. H., Ertaş, M., Nitz, S., and Kollmannsberger H. "Chemical composition and content of essential oil from the bud of cultivated turkish clove (Syzygium aromaticum L.)," BioResources, vol. 2, pp. 265-269, 2007.

[15] Bajalan I., and Pirbalouti, A. G., "Variation in chemical composition of essential oil of populations of Lavandula $\times$ intermedia collected from Western Iran", Ind. Crop. Prod., vol. 69, pp. 344-347, 2015

[16] Zou, Y., "Lavender Oil Analysis Using Agilent J \& W DB-WAX Ultra Inert Capillary GC Columns", Agilent Technologies Ltd, p. 8, 2016.

[17] Djemaa, F. G. B., Bellassoued, K., Zouari, S., Feki, A. E., and Ammar, E., "Antioxidant and wound healing activity of Lavandula aspic L . ointment," J. Tissue Viability, vol. 25, pp. 193-200, 2016.

[18] Piñeros-Hernández, D., Medina-Jaramillo, C., López-Córdoba, A., and Goyanes, S., "Edible cassava starch films carrying rosemary antioxidant extracts for potential use as active food packaging", Food Hydrocoll., vol. 63, pp. 488-495, 2017.

[19] Sánchez-Vioque, R., Izquierdo-Melero, M. E., Polissiou, M., Astraka, K., Tarantilis, P. A., Herraiz-Peñalver, D., MartínBejerano, M., and Santana-Méridas, O., "Comparative chemistry and biological properties of the solid residues from hydrodistillation of Spanish populations of Rosmarinus officinalis L.," Grasas y Aceites, vol. 66, 2015.

[20] Yang, Y., Song, X., Sui, X., Qi, B., Wang, Z., Li, Y., and Jiang, L., "Rosemary extract can be used as a synthetic antioxidant to improve vegetable oil oxidative stability," Ind. Crop. Prod., vol. 80, pp. 141-147, 2016.

[21] Wollinger, A., Perrin, É., Chahboun, J., Jeannot, V., Touraud, D., and Kunz, W., "Antioxidant activity of hydro distillation water residues from Rosmarinus of fi cinalis L . leaves determined by DPPH assays," Comtes Rendus Chim., pp. 1-12, 2016.

[22] Li, B., Zhang, C., Peng, L., Liang, Z., Yan, X., Zhu, Y., Liu, Y., "Comparison of essential oil composition and phenolic acid content of selected Salvia species measured by GC - MS and HPLC methods," Ind. Crop. Prod., vol. 69, pp. 329-334, 2015.

[23] Porte, A., Godoy, R. L. O., and Maia-Porte, R. H., "Chemical composition of sage (Salvia officinalis L .) essential oil from the Rio de Janeiro State ( Brazil )," Rev. Bras. Pl. Med., vol. 15, pp. 438-441, 2013.

[24] Bernotienè, G., Nivinskiené, O., Butkiené, R., and Mockute, D., "Essential oil composition variability in sage (Salvia officinalis L .)," CHEMIJA, vol. 18, pp. 38-43, 2007.

[25] Ramírez-Godínez, J., Jaimez-Ordaz, J., Añorve-Morga, J. Salazar-Pereda, V., Castañeda-Ovando, González Olivares, G., and Contreras-López, E., "Determinación de actividad antioxidante en extractos acuosos de cedrón (Aloysia triphylla)", 2016.

[26] Dos Santos, A. C., Sutili, F. J., Heinzmann, B. M., Cunha, M. A., Brusq,ue, I. C. M., Baldisserotto, B., and Zeppenfeld, C. C., "Fish \& Shell fi sh Immunology Aloysia triphylla essential oil as additive in silver cat fi sh diet: Blood response and resistance against Aeromonas hydrophila infection", Fish Shellfish Immunol., vol. 62, pp. 213-216, 2017.

[27] Santos-gomes, P. C., Fernandes-Ferreira, M., and Vicente, A. M. S., "Composition of the Essential Oils from Flowers and Leaves of Vervain [Aloysia triphylla (L'Herit.) Britton] Grown in Portugal", J. Essent. Oil Res., vol. 17, pp. 73-78, 2014.

[28] Olmedo, R. H., Nepote, V., and Grosso, N. R., "Preservation of sensory and chemical properties in flavoured cheese prepared with cream cheese base using oregano and rosemary essential oils", LWT - Food Sci. Technol., vol. 53, no. 2, pp. 409-417, 2013.

[29] Parodi, T. V., Cunha, M. A., Heldwein, C. G., De Souza, D. M., Martins, Á. C., O. Garcia, L., Junior, W. W., Moserrat, J. M., Schmidt, D., Caron, B. O., Heinzmann, B., and Baldisserotto, B.,"The anesthetic efficacy of eugenol and the essential oils of Lippia alba and Aloysia triphylla in post-larvae and sub-adults of Litopenaeus vannamei (Crustacea, Penaeidae)", Comp. Biochem. Physiol. Part C, vol. 155, no. 3, pp. 462-468, 2012. 